\title{
Trypanosomes of Non-human Primates from the National Centre of Primates, Ananindeua, State of Pará, Brazil
}

\author{
Mariangela Ziccardi ${ }^{+}$, Ricardo Lourenço-de-Oliveira, Ralph Lainson*, \\ Maria do Carmo de Oliveira Brígido**, José Augusto Pereira Carneiro Muniz**
}

\author{
Laboratório de Transmissores de Hematozoários, Instituto Oswaldo Cruz, Av. Brasil 4365, 21045-900 Rio de \\ Janeiro, RJ, Brasil *Departamento de Parasitologia, Instituto Evandro Chagas, Caixa Postal 1128, 66090-000 \\ Belém, PA, Brasil **Centro Nacional de Primatas, FNS, BR 316 km 7, 67030-000 Ananindeua, PA, Brasil
}

Trypanosome infections were sought in 46 non-human primates captured principally in Amazonian Brazil. Twenty-two (47.8\%) were infected with four Trypanosoma species: T. cruzi, T. minasense, T. devei and $\mathrm{T}$. rangeli.

These preliminary results confirmed the high prevalence and diversity of natural infections with trypanosomes in primates from Brazilian Amazon and were the first formal record of simian infections with trypanosomes in the State of Acre. The presence of $T$. cruzi-like and T. rangeli-like parasites are recorded in four new hosts.

Key words: Trypanosoma cruzi - Trypanosoma rangeli - Trypanosoma minasense - Trypanosoma devei

The trypanosomes are among the most frequent parasites reported in neotropical non-human primates. The prevalence, taxonomy, biology and transmission of most species, however, have been poorly characterized.

Trypanosome infections were sought in nonhuman primates captured principally in Amazonian Brazil and maintained in the National Centre of Primates, Ananindeua, State of Pará, Brazil, where animals are raised and maintained for biomedical research. Blood samples of 46 primates (41 wild-caught [w], 4 born in captivity [c] and 1 domicile donation [d]) were obtained from the following species: 10 mustached tamarins [w] Saguinus imperator imperator (Goeldi); 7 marmosets [w] Callithrix penicillata (Geoffroy); 6 saddle back tamarins [w] Saguinus fuscicollis weddelli (Deville); 6 howler monkeys [w] Alouatta caraya (Humboldt); 4 squirrel monkeys [w] Saimiri boliviensis (Geoffroy \& Blainville); 4 Goeldi's monkeys [w] Callimico goeldii (Thomas); 3 sakis [c] Pithecia irrorata Gray; 3 bearded sakis [2w,

\footnotetext{
Awarded poster in International Symposium on the Advances in Knowledge of Chagas Disease 90 Years after its Discovery.

${ }^{+}$Corresponding author. Fax: +55-21-290-9339. E-mail: ziccardi@gene.dbbm.fiocruz.br

Received 20 July 1999

Accepted 28 December 1999
}

1c] Chiropotes satanas utahicki Hershkovitz; 2 pygmy marmosets [w] Cebuella pygmaea (Spix); 1 titi [d] Callicebus donacophilus (d'Orbigny). The nomenclature and systematics of the primates used here are those adopted by (Hershkovitz 1985, Coimbra Filho 1990, Wilson \& Reeder 1993).

Examination was by way of Giemsa-stained thick and thin blood smears (BS), haemoculture (HC) made with Novy, McNeal and Nicolle (NNN) medium plus Liver Infusion Tryptose (LIT), and xenodiagnosis (XD) using six nymphs of Rhodnius prolixus Stal.

Fifteen Trypanosoma isolates were made, and subsequently cryopreserved in liquid nitrogen for further characterization.

Twenty-two $(47.8 \%)$ of the animals were infected with trypanosomes. Four Trypanosoma species were detected: Trypanosoma (Schizotrypanum) cruzi Chagas, T. (Megatrypanum) minasense Chagas, T. (Megatrypanum) devei Leger $\&$ Porry (Figure) and $T$. (Tejeraia) rangeli Tejera.

The most common trypanosome species infecting the primates was T. rangeli-like, found in $30.4 \%$ (14/46) of individuals, followed by T. devei (12/ 46) and $T$. cruzi-like (4/46) which accounted for $8.7 \%$ of the total examined. T. minasense was found in $4.3 \%$.

T. cruzi were detected in one animal from three species: C. pygmaea (50\%) by XD, S. i. imperator (10\%) and S.f. weddelli (16.7\%); both detected by BS and HC; all of them are from the State of Acre. One $C$. penicillata $(14.3 \%)$ showed $T$. cruzi by HC; 

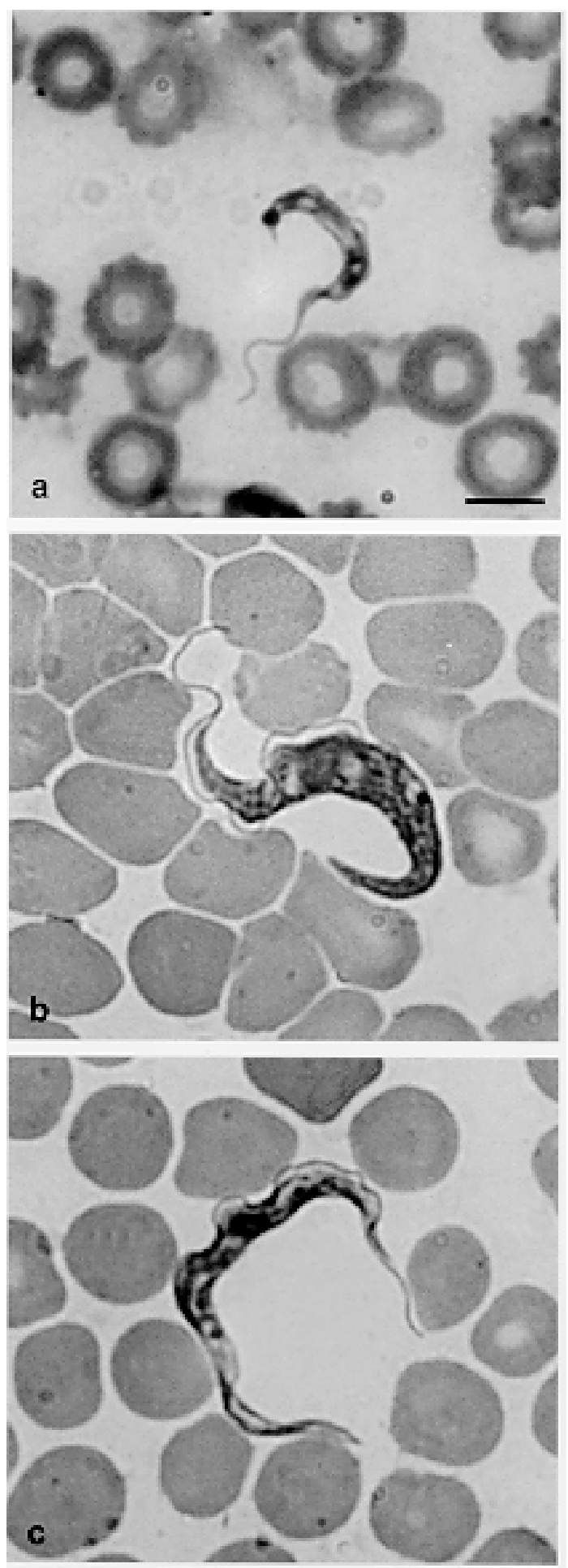

Photomicrographs of trypomastigotes found in thin blood smears from naturally infected tamarin, Saguinus fuscicollis weddelli, from Ananindeua, Pará. a: Trypanosoma cruzi; b: T. minasense; c: T. devei. Bar $=10 \mu \mathrm{m}$. this animal were from the State of Goiás, in Central Brazil. T. rangeli-like parasites were isolated by $\mathrm{HC}$ from 13 (28.3\%) specimens of primates caught in Acre, as follows: 4 S. i. imperator (40\%); 1 S. f. weddelli $(16.6 \%) ; 4$ S. boliviensis $(100 \%) ; 1$ C. pygmaea $(50 \%)$ and 3 C. goeldii $(75 \%)$.

Seven S. i. imperator (70\%), 2 S. f. weddelli (33.3\%), 1 C. pygmaea (50\%) and 2 C. goeldii (50\%) were infected with T. devei. T. minasense was detected in one $S$. $f$. weddelli and $1 S$. $i$. imperator. These species of trypanosomes were detected only in the BS. All laboratory-raised primates were negative.

These preliminary results confirm the high prevalence and diversity of natural infections with trypanosomes in primates from Brazilian Amazon (Deane \& Damasceno 1961, Deane et al. 1970, 1972, Lourenço-de-Oliveira 1988, Ziccardi \& Lourenço-de-Oliveira 1997). The presence of $T$. cruzi-like and $T$. rangeli-like parasites are thus recorded in four new hosts: C. pygmaea, $C$. goeldii, S. i. imperator and S. f. weddelli. This is the first formal record of simian infections with T. cruzilike and $T$. rangeli-like trypanosomes, $T$. minasense and $T$. devei in the State of Acre, Brazilian Amazon. The late Professor LM Deane examined 92 primates from Acre and found T. cruzi, T. minasense and $T$. devei among 81 individuals of 17 species (unpublished data).

Naturally acquired infections in animals used for experimental purposes are potential sources of accidental transmission to handlers and uninfected monkeys (Sullivan et al. 1993). They may also introduce confounding variables into experimental studies.

\section{ACKNOWLEDGMENTS}

To Genilton Vieira, Heloísa Diniz, Rodrigo Mexas, Marcos Ribeiro, Dayse Branco and Maria Auxiliadora de Sousa for aid with photomicrographs and Claudio Meneses for helping poster design.

\section{REFERENCES}

Coimbra Filho AF 1990. Sistemática, distribuição geográfica e situação atual dos símios brasileiros (Platyrrhini = Primates). Rev Brasil Biol 50: 10631079.

Deane LM, Damasceno RG 1961. Tripanosomídeos de mamíferos da Região Amazônica II. Tripanosomas de macacos da Zona do Salgado, Estado do Pará. Rev Inst Med Trop São Paulo 3: 61-70.

Deane LM, Almeida FB, Ferreira Neto JA, Evangelista da Silva J 1972. Trypanosoma cruzi e outros tripanosomas em primatas brasileiros. Rev Soc Bras Med Trop 4: 361.

Deane LM, Batista D, Ferreira Neto JA, Souza H 1970. Tripanosomídeos de mamíferos da Região Amazônica V. Trypanosoma lambrechti Marinkelle, 
1968, em macacos da Zona do Salgado, Estado do Pará. Rev Inst Med Trop São Paulo 12: 1-7.

Hershkovitz P 1985. A preliminary taxonomic review of the South American bearded saki monkeys genus Chiropotes (Cebidae, Platyrrhini), with the description of a new subspecies. Fieldiana Zool 27: 1-46.

Lourenço-de-Oliveira R 1988. Hemoparasitos encontrados em alguns mamíferos de Balbina, Estado do Amazonas. Mem Inst Oswaldo Cruz 83: 233.

Sullivan JJ, Steurer F, Benavides G, Tarleton RL,
Eberhard ML, Landry S 1993. Trypanosomes and microfilariae in feral owl and squirrel monkeys maintained in research colonies. Am J Trop Med Hyg 49: 254-259.

Wilson DE, Reeder DM 1993. Mammal Species of the World: a Taxonomic and Geographic Reference, 2nd ed., Smithsonian Institution, Washington and London, 1206 pp.

Ziccardi M, Lourenço-de-Oliveira R 1997. The infection rates of trypanosomes in squirrel monkeys at two sites in the Brazilian Amazon. Mem Inst Oswaldo Cruz 92: 465-470. 